\section{Nutraceutical in male reproduction}

\author{
Nutracêuticos na reprodução do macho
}

\author{
Mariane Leão Freitas ${ }^{1 *}$ \& Rodrigo Arruda de Oliveira ${ }^{1}$ \\ 'Médicos veterinários, Reprodução Animal. Faculdade de Agronomia e Medicina Veterinária, Universidade de Brasília - UnB, \\ Campus Universitário Darcy Ribeiro, Brasília, DF, Brasil
}

\begin{abstract}
In order to obtain a successful outcome in artificial insemination programs, a few precautions must be taken with regard to male breeders. It is established that environmental factors can change the hormonal secretion, the cell differentiation that occurs in the testicles, as well as sperm maturation and transport in the epididymis. In view of adverse nutritional factors, reproductive organs can present degeneration and disorders in different degrees and intensities, affecting the animal fertility. The term nutraceutical describes products derived from foods, which may provide additional health benefits, beyond the basic value found in diets. Among the main nutraceuticals used in male reproduction, there are omega-3, arginine, B-complex vitamins, L-carnitine, $\beta$-carotene and antioxidants. The aim of this paper is to present the main substances used as nutraceuticals, in order to improve semen quality, obtaining most favorable outcomes of stallions in the use of natural breeding or artificial insemination.
\end{abstract}

Keywords: artificial insemination, fertility, nutrition, semen, spermatogenesis.

\section{Resumo}

Para um sucesso em programas de inseminação artificial, algumas precauções devem ser tomadas em relação aos reprodutores machos. Sabe-se que fatores ambientais podem alterar a secreção hormonal, a diferenciação celular que ocorre nos testículos, assim como o transporte e a maturação espermática no epidídimo. Um déficit nutricional pode levar a degeneração e distúrbios dos órgãos reprodutivos em diferentes graus e intensidade, afetando a fertilidade. O termo nutracêutico descreve produtos derivados dos alimentos, que podem fornecer benefícios adicionais a saúde, além dos valores básicos encontrados na dieta. Entre os vários nutracêuticos utilizados na reprodução, temos o ômega-3, arginina, vitaminas do complexo B, L-carnitina, $\beta$-caroteno e antioxidantes. Objetivou-se com essa revisão apresentar as principais substâncias utilizadas como nutracêuticos, com a finalidade de melhorar a qualidade seminal, obtendo resultados favoráveis dos garanhões com a monta natural ou a inseminação artificial.

Palavras-chave: inseminação artificial, fertilidade, nutrição, sêmen, espermatogênese.

\section{Introduction}

Spermatogenesis, the male gamete formation process, which takes place in the testicles, more specifically in the seminiferous tubules, demand that the function of all body systems are balanced, taking into knowledge the sensitivity of the germinal epithelium. It is established that environmental factors can change the hormonal secretion, the cell differentiation that occurs in the testicles, as well as sperm maturation and transport in the epididymis. In view of adverse factors, especially nutritional, reproductive organs can present degeneration and disorders in different degrees and intensities, temporary or permanent, thereby, determining the amount of the influence on the animal fertility (Arruda et al., 2010).

The industry has released on the market a number of substances, with the intent to optimize the use of nutrients in some metabolic pathways, positively influencing the reproductive performance of animals (Arruda et al., 2010; Freitas et al., 2016).

The term nutraceutical describes products derived from foods, which may provide additional health benefits, beyond the basic value found in diets (Dharti et al., 2010). In this way, nutraceuticals are among food and pharmaceuticals. Nutraceutical is, therefore, used as a comprehensive term, including substances of vegetable origin and by-products, supplements, minerals and vitamins (Ko \& Sabanegh, 2014).

The aim of this paper is to present the main substances used as nutraceuticals, supplied either isolated or in combination with other substances, in order to improve semen quality, obtaining most favorable outcomes of stallions in the use of natural breeding or artificial insemination.
How to cite: Freitas, M. L., \& Oliveira, R. A. (2018). Nutraceutical in male reproduction. Brazilian Journal of Veterinary Medicine,40, e220118. doi: 10.29374/2527-2179.bjvm220118

\section{Financial support: None}

Conflict of interests: No conflict of interests declared concerning the publication of this article.

Received: July 03, 2017.

Accepted: October 04, 2017

The study was carried out at Universidade de Brasília - UnB, Brasília, DF, Brasil.

\section{*Correspondence}

Mariane Leão Freitas

Faculdade de Agronomia e Medicina Veterinária, Universidade de Brasília - UnB,

Campus Universitário Darcy Ribeiro Asa Norte, CEP 70910-900 - Brasilia (DF), Brasil

E-mail: rodrigoarruda@unb.br
Copyright Freitas et al. This is an Open Access article distributed under the terms of the Creative Commons Attribution Non-Commercial License which permits unrestricted non-commercial use, distribution, and reproduction in any medium provided the original work is properly cited. 


\section{Main nutraceuticals used in male reproduction}

Among the main nutraceuticals used in male reproduction, there are omega-3, arginine, B-complex vitamins, L-carnitine, $\beta$-carotene and antioxidants.

\section{Omega-3}

Semen from all domestic species contains high levels of polyunsaturated fatty acids (PUFA), especially docosahexaenoic acid (DHA; 22: 6 n-3 fatty acid omega-3) and docosapentaenoic acid (DPA, 22: 5 n-6, an omega-6 fatty acid). These fatty acids are essential for the structure, function and integrity of the plasma membrane (Colenbrander et al., 1992). Thus, maintenance of the membrane is essential for the continuous cellular viability (Grady et al., 2009; Freitas et al., 2016).

Since animals are unable to synthesize PUFAs from saturated or monounsaturated fatty acids, they must acquire them from precursors PUFAs in their diet. The transfer of dietary PUFAs to the plasma membrane of sperm has been shown to be effective in some species, such as small ruminants (Drokin et al., 1999) and humans (Conquer et al., 2000). Decrease of fertility during aging was associated with a reduction in the proportion of specific phospholipids PUFAs, both in bull sperm (DHA; Kelso et al., 1997) and in chicken sperm (C2O-22 PUFA; Cerolini et al., 1997).

High levels of PUFAs increase the susceptibility of cells to induced damage by free radicals, which is considered an important cause of infertility on men (Aitken, 1994). According to Gliozzi et al. (2009), it is essential to consider a critical balance between lipids, reactive oxygen species and the different components of the cell's antioxidant system, to ensure an efficient functionality of sperm.

Studies in stallions, demonstrated that a larger proportion of DHA compared to DPA results in higher fertility, while higher levels of DPA in relation to DHA results in a lower fertility (Brinsko et al., 2005). In azoospermic men, it was found that, the level of DHA in seminal plasma, as well as the ratio of omega-3 regarding omega- 6 fatty acids in spermatozoa is lower than in normospermic men (Conquer et al., 1999).

Yeste et al. (2011) compared the effect of omega-3 supplementation for 26 weeks in the diet of three different breeds of boars (Pietrain, Duroc and Large White), and discovered that only Pietrain and Large White breeds were affected by supplementation. There was observed an improvement in sperm morphology of these two breeds, and increase in acrossomal and mitochondrial integrity of the Pietrain breed. The Duroc breed suffered no influence of dietary supplementation. Thus, these authors were able to conclude that there are differences in the response to nutritional supplementation towards breeds, when it comes to semen quality. This occurs because there are peculiarities in the composition of the plasma membrane sperm of different breeds.

Grady et al. (2009), observed that supplementation of docosahexaenoic acid in the diet of stallions can increase the daily production of sperm, the quality of cooled and cryopreserved semen. Possibly, due to an increase in DHA content in the plasma membrane of sperm. The effect was magnified in stallions initially with poor quality ejaculates.

Schmid-Lausigk \& Aurich (2014), investigated the addition of linseed oil (omega-3 and omega-6) in association with antioxidants in diet of stallions, during the harsh winter. They evaluated the effect of supplementation on sperm motility and integrity of plasma membrane, for cooled and frozen-thawed semen. According to the authors, during the winter, there might be changes in lipid composition of the plasma membrane of sperm, due to changes in reproductive physiology. Leading to a decline in semen quality of stallions. In conclusion, treatment with linseed oil and antioxidants, attenuated the decrease in sperm motility and integrity of plasma membrane in cooled semen, of stallions that received supplementation. However, did not prevent the decline of sperm quality of frozen-thawed semen at the end of winter.

\section{Arginine}

Arginine is an amino acid, which is involved in the synthesis of nitric oxide. Nitric oxide is a gas that is formed in aqueous medium, by conversion of arginine in the presence of oxygen and divers co-factors (Knowles et al., 1989). Nitric oxide participates in very important physiological mechanisms, acting as an intracellular messenger in the control of vascular tone, neurotransmission, 
in hormone production, cell differentiation, gene expression and activation of cells of the immune system (O'Bryan et al., 1998).

Nitric oxide acts on the hypothalamus, through the stimulation of the release of gonadotropin releasing hormone (GnRH) and inhibiting the release of oxytocin. The GnRH, in the pituitary level, stimulates the release of luteinizing hormone (LH) and follicle-stimulating hormone (FSH). A decrease in the concentration of hypothalamic nitric oxide can cause damage to the reproductive role, since it is the one responsible for the functioning of the reproductive axis, are of fundamental importance for normal reproduction (McCann et al., 1999).

The presence of nitric oxide in the seminal fluid is also essential for sperm, so it can have full capacity to perform its gamete function. Furthermore, in the reproductive system, nitric oxide plays as regulator in the relaxation of smooth muscle of cavernous body of the penis and its afferent blood vessels (Adams, 1996), facilitating erection (Dusse et al., 2003).

However, when occurs an excessive production of nitric oxide, not only it causes damage to the gamete structure, but also reduces their mobility and vitality. Though, on the other hand, very low concentrations may interfere in the process of fertilization and at the beginning of cell division of the new embryo (Carvalho et al., 2002).

Reports of the effect of arginine on the semen parameters differ in the literature. Some studies have reported that daily supplementation of arginine improves semen concentration and sperm motility (Holt \& Albanese, 1944; Tanimura, 1967; Schachter et al., 1973; De-Aloysio et al., 1982; Scibona et al., 1994), while other authors did not succeed on showing any improvement in sperm characteristics or pregnancy rate (Mroueh, 1970; Pryor et al., 1978). There are also studies that have shown that arginine in excessive concentrations results in decrease on sperm function (Srivastava \& Agarwal, 2010).

\section{B-complex vitamins}

Vitamin B12 (cobalamin) is a water-soluble vitamin, and a component of the animal organism and metabolism (Solomon, 2007). The primary function of vitamin B12 is to act as a coenzyme to reduce ribonucleotides to deoxyribonucleotides, essential in the genes replication. In addition, cobalamin operates in the stimulation of growth, the stimulation of synthesis and cellular maturation, and helps to maintain the stability of DNA chromatin. The vitamin B12 deficiency leads to the accumulation of methylmalonic acid, which can affect and interrupt the mitochondrial metabolism, leading to excessive production of reactive oxygen species (ROS; Al-Maskari et al., 2012).

The folic acid (vitamin B9), is another water-soluble B-complex vitamin that plays an important role in DNA synthesis, through the synthesis of purine and thymine (Al-Maskari et al., 2012). Adequate intake of folic acid is associated with a decrease in the frequency of DNA alterations in sperm (Young et al., 2008).

Folic acid is closely linked to vitamin B12, because depends on it to fulfill its function (Al-Maskari et al., 2012). Thereby, the combination of folic acid and the cobalamin in supplementation programs benefits and maximizes the impact of these vitamins, taking into consideration that vitamin B12 makes folic acid more bioavailable, and that cobalamin deficiency render vitamin B9 unavailable to the organism (Reynolds, 2006; Solomon, 2007).

Consequently, the deficiency of these two factors leads to chromosomal abnormalities and increased ROS, causing a risk of genetic mutations (Al-Maskari et al., 2012).

\section{L-carnitine}

Another component of nutraceuticals destined at reproduction is L-carnitine. L-carnitine is synthesized in the liver, kidney and brain, by conversion of two essential amino acids, lysine and methionine. L-carnitine plays a vital role in cellular energy metabolism. It functions as a transporter of short, medium and long chain fatty acids to or through the internal mitochondrial membrane, thereby facilitating the $\beta$-oxidation (Hulse et al.,1978; Jeulin et al., 1994). Thus, carnitine provides energy and operates in motility and maturation of sperm (Palmero et al., 2000).

High concentrations of carnitine are present both in seminal plasma and in the sperm, in which L-carnitine reduces the availability of lipids to peroxidation (Neuman et al., 2002). Then we can 
say that, secondarily, L-carnitine also acts as an antioxidant, which provides protection against ROS (Vicari et al., 2002).

In men, the amount of $\mathrm{L}$-carnitine in seminal plasma is related to the concentration and progress motility of sperm (Menchini-Fabris et al., 1984; Bornman et al., 1989). It was reported a significant reduction in the concentration of carnitine in the semen of patients with azoospermia, affected by bilateral agenesis of the vas deferens and epididymis obstruction (Menchini-Fabris et al., 1984; Casano et al., 1987). The reduction in carnitine of seminal plasma was also reported in infertile patients (Zöpfgen et al., 2000). The positive correlation between semen parameters and carnitine concentration in semen, enables to propose that carnitine is a marker of "good quality" of semen (Menchini-Fabris et al., 1984).

Kozink et al. (2004), supplemented boars with 500 mg L-carnitine/day for 16 weeks, and collected semen of these animals every week, and for four consecutive days at week 16. For either weekly semen collection as for the intensive collections, were not found consistent positive effects for the treatment in semen volume, sperm concentration and in total and progressive motility of the semen. Reaching the conclusion that there was no improvement in semen quality of boars submitted to supplementation with L-carnitine.

\section{$\beta$ - carotene/Vitamin A}

Vitamin A, also known as carotenoid or retinoid, is a fat-soluble vitamin, which is required for maintaining epithelium that recovers all channels, cavities and areas of external exposure, which vitamin A acts directly on mucopolysaccharides synthesis (Bertechini, 1997). Consequently, being responsible for the conservation of the mucous membranes of eyes, gastrointestinal tract and genitourinary tract, beside the skin (Kamal-Eldin \& Appelqvist, 1996). The keratinization of epithelia is the result of the loss of its secretory capacity, making it dry and susceptible to infections (Bertechini, 1997).

Vitamin A as retinol, retinaldehyde or retinoic acid is only found in the animal's organism and its products. However, plants produce yellow pigments called carotenoids (provitamin A), that can be converted into vitamin $A$ in the animals intestine and liver, with an efficiency that varies with the species, whereas $\beta$-carotene is the most important provitamin A (Bertechini, 1997).

In the literature, we can find that $\beta$-carotene acts beneficially into the body, the same way as vitamin A, and it is essential for epithelial tissues that are present in reproductive organs (Arikan \& Rodway, 2000). In reproduction, Vitamin A acts on the synthesis of steroid hormones, obtained from the organic cholesterol, which takes place in the gonads, placenta, and adrenal gland. In case of deficiency, it might occur histological changes of the reproductive organs of both males and females, rendering the reproductive glands atrophic (Bertechini, 1997).

In this way, vitamin A exerts a strong influence on the male reproductive complex, acting as protector of the testicular epithelium, through the action on the gametogenesis; stimulating libido and sexual vigor, together with vitamin $\mathrm{C}$ and $\mathrm{B}$ complex vitamins; and enhacing the motility and volume of the ejaculate (Rillo, 1982).

According to Rillo (1982), vitamin A deficiency results in vacuolization of basophil cells, leading to degenerate and prevent the development of gonadotropic factors and, consequently, inhibiting sperm production.

Preliminary studies in rats indicated that spermatogenesis is affected by vitamin A. In animals that suffer deficiency of this vitamin, the seminiferous tubules contain only Sertoli cells, spermatogonias and some spermatocytes, being absent the developing germ cells that are essential for spermatogenesis (Wolbach \& Howe, 1925; Mason, 1933).

Erb et al. (1947) found that young bulls receiving food with low vitamin A content presented: weight loss, impaired vision, seizures, decreased spermatogenesis and testicular atrophy. In adult bulls, there were no cases of sterility, but vitamin A deficiency generated a lower capacity of fertilization, as consequence of low semen quality.

Bratton et al. (1948), submitted 6 bulls to diet with a lack of provitamin A during a period of 21 months. At the end of the experiment, three bulls showed decreased semen motility and increased abnormal sperm forms. Histologically, the germinal epithelium of seminiferous tubules presented signs of degeneration, and a low number of cells in the seminiferous tubules lumen. 


\section{Antioxidants}

Like all living cells under aerobic conditions, spermatozoids produce reactive oxygen species (ROS), as a result of normal metabolism of oxygen (Lamirande et al., 1997). The plasma membrane of mammalian sperm contains a high concentration of long chain polyunsaturated fatty acids, therefore, spermatozoids are highly susceptible to lipid peroxidation (Jones \& Mann, 1973; Aitken et al., 1993).

Under normal conditions, enzymatic or low molecular weight scavengers, contained in the spermatozoa and seminal plasma, continually neutralize most of the reactive oxygen species (Lamirande et al.,1997). Oxidative stress appears as a consequence of excessive ROS production, that results in a decrease of intracellular ATP levels, leading to lipid peroxidation of the plasma membrane of sperm (Almeida \& Ball, 2005).

Subsequent to the lipid peroxidation, it may befall a decrease of plasma membrane integrity, DNA damage, a reduction of intrinsic ability of sperm to repair DNA damage (Ryan et al., 1990), and a decline in sperm motility (Kao et al., 2008). Despite the negative effects of excessive oxidative stress, physiological reactive oxygen species, are essential for certain functions of the sperm, including spermatic capacitation (Lamirande \& Lamothe, 2009).

Mammalian sperm have an intracellular antioxidant defense system against ROS, that consists mainly of enzymes such as superoxide dismutase, catalase, glutathione transferase and glutathione peroxidase (GPx), as well as non-enzymatic antioxidants, such as ascorbic acid (vitamin C), $\alpha$-tocopherol (vitamin E), urate, and reduced glutathione (Cotgreave et al., 1988; Aitken et al., 1995).

\section{Vitamin E}

Vitamin $\mathrm{E}$ ( $\alpha$-tocopherol) is a fat-soluble vitamin considered as a potent antioxidant, acting at the level of cell membranes (Ford \& Whittington, 1998). $\alpha$-tocopherol protects the sperm plasma membrane, inhibiting free radical induced damage, preventing lipid peroxidation, and improving the activity of other antioxidants (Palamanda \& Kehrer, 1993; Brigelius-Flohe \& Traber, 1999). It is efficient at removing peroxyl radicals, therefore, being able to interrupt the chain of reactions involving this free radical (Vignini et al., 2011).

According to Vignini et al. (2011), other functions of $\alpha$-tocopherol are related to the stabilization of the plasma membrane, through a complex formation involving the hydrolysis products of vitamin $\mathrm{E}$ and free fatty acids in the plasma membrane.

Surai et al. (2000) reported that cryopreserved semen is related to a significant reduction in sperm motility induced by ROS, and these effects can be combated effectively by adding vitamin E to freezing extenders.

\section{Vitamin C}

Ascorbic acid (vitamin C) is another non-enzymatic component that acts as an antioxidant. Vitamin C is a water-soluble vitamin, which is known to remove effectively hydroxyl, superoxide and hydrogen peroxide radicals, and plays an important role in the recycling of oxidized vitamin $\mathrm{E}$ (Kefer et al., 2009). In appropriate concentrations, vitamin C reduces fragmentation and DNA damage in sperm. (Greco et al., 2005; Colagar \& Marzony, 2009; Mendiola et al., 2010). Ascorbic acid is found in high concentrations in seminal plasma, being proportional to its consumption (Dawson et al., 1987).

The efficiency of ascorbic acid as an antioxidant was demonstrated in studies, where the ascorbic acid supplementation has a beneficial effect on semen characteristics and testosterone levels in rabbits (Salem et al., 2001). Thiele et al. (1995) suggested that the concentration of vitamin C in human seminal plasma is positively correlated with morphologically normal sperm percentages; also, it was proposed that this vitamin is an epididymis protector, protecting cell membranes by its antioxidant effect.

Chinoy et al. (1986) reported that ascorbic acid is important for the physiological preservation of testis, epididymis and accessory glands integrity and, that deficiency of vitamin C in diet cause rapid degeneration of the reproductive system as a whole.

Sonmez et al. (2005) studied the effects of ascorbic acid supplementation on semen quality, lipid peroxidation and testosterone levels in the blood plasma of Wistar rats. These authors concluded 
that ascorbic acid supplementation did not increase body weight, testicles, epididymides, seminal vesicles and prostate weight, but increased significantly the concentration of ascorbic acid in the testicles and blood plasma, reducing considerably the levels of lipid peroxidation.

\section{Glutathione peroxidase, Selenium and others Trace elements}

Among enzymatic systems, there is glutathione peroxidase (GPx), that catalyzes the reduction of hydrogen peroxide and other organic peroxides (lipid peroxides in the cell membrane), to their corresponding alcohols. Converting glutathione - reduced form (GSH) to Glutathione - oxidized form (GSSG), which contains two molecules linked by a disulfide bond. GPx contains a selenium atom, bonded covalently in the form of selenocysteine, that is essential for this enzyme carries out its activity (Nordberg \& Árner, 2001; Maiorino et al., 2003; Oliveira et al., 2013).

In mammals exists GPx 1 to 4 . Recently, it was found that GPx 4 has a dual function in sperm cells: it is enzymatically active in the spermatid; and functions as a structural protein in mature spermatozoa. It was also emphasized that, GPx 4 can react with hydrogen peroxide, and a wide variety of lipid hydroperoxides and, therefore, considered responsible for protecting the sperm membrane against oxidative damages (Imai \& Nakagawa, 2003).

In the testes, GPx 4 is present in three different isoforms, which are derived from the same genes, and localized in the cytosol, nucleus and mitochondria. It serves to assist in the development of sperm through the protection against reactive oxygen species. This corroborates with studies conducted in humans, where it was observed that men with low fertility, due to reduced concentration and poor sperm quality, contained little GPx in sperm (Beckett \& Arthur, 2005).

Selenium exists in various forms and has been recognized as essential for reproduction. It plays a major role in male fertility, not just for taking part in regulation of several physiological functions, including protecting the sperm through antioxidant action and stabilization of sperm membrane, but also for being indispensable in testosterone synthesis (Crimmel et al., 2001).

Selenium is a component of glutathione peroxidase and act as a cofactor for reduction of antioxidant enzymes (Brown \& Arthur, 2001). According Hafeman et al. (1974), the activity of glutathione peroxidase in tissues of rats decrease dramatically in animals with diets restricted in selenium, and increases when selenium is restored.

Moreover, selenium has an important role in the maintenance of testicular development, spermatogenesis, and sperm functions. Such as motility and sperm capacitation (Ursini et al.,1999). Negative effects of selenium deficiency include decreased sperm motility, decreased stability of the sperm mid piece, and abnormal development of spermatozoa, resulting in an elevated rate of morphological defects (Watanable \& Endo, 1991; Noack-Füller et al., 1993).

It was noted that selenium increases the sperm concentration and motility, and decreases the number of morphological defects, when used alone or in combination with other antioxidants and supplements (Vezina et al., 1996; Safarinejad \& Safarinejad, 2009). Vitamin E plays a role in selenium metabolism and acts in synergy with antioxidant properties of selenium (Burton \& Traber, 1990).

Zinc, copper and manganese are trace elements that are important for the antioxidant defense system of semen against ROS. They play a role on the enzymatic activity of superoxide dismutase, another important catalytic enzyme that inactivates oxidants (Kirschvink et al., 2008). Also, Pesch et al. (2006), observed that zinc concentration in semen present a positive correlation with sperm concentration.

\section{Conclusions}

Caring for the animal nutrition is essential to achieve good results in reproduction. There are some products in the industry, which feature in its formulation a range of nutraceutical substances, in order to improve the performance of animals used for breeding. However, we have to take into account, that the outcome of nutraceutical supplementation vary for each individual, according to species, breed, age, and with environment and nutritional factors.

Many studies were performed to evaluate the use of nutraceuticals in the male reproduction, both in humans and in animals. Though, there is no standard methodology in these studies and, consequently, in the acquired results. Therefore, it is necessary to conduct further studies, where 
every nutraceutical be evaluated independently, within each species. And then, be possible for us, to determine the actual function of each substance, in the male reproductive system and, thus, define the optimal dose of every nutraceutical according to species or breed of interest.

\section{References}

Adams, H. R. (1996). Physiologic, pathophysiologic, and therapeutic implications for endogenous nitric oxide. Journal of the American Veterinary Medical Association, 209(7), 1297-1302. PMid:8837656.

Aitken, R. J. (1994). A free radical theory of male infertility. Reproduction, Fertility, and Development, 6(1), 19-23, discussion 23-24. http://dx.doi.org/10.1071/RD9940019. PMid:8066217.

Aitken, R. J., Harkiss, D. U., \& Buckingham, D. E. (1993). Analysis of lipid peroxidation mechanism in human spermatozoa. Molecular Reproduction and Development, 35(3), 302-315. http://dx.doi.org/10.1002/mrd.1080350313. PMid:8352936.

Aitken, R. J., Paterson, M., Fisher, H., Buckingham, D. W., \& van Duin, M. (1995). Redox regulation of tyrosine phosphorylation in human spermatozoa and its role on the control of human sperm function. Journal of Cell Science, 108(Pt 5), 2017-2025. PMid:7544800.

Al-Maskari, M. Y., Waly, M. I., Ali, A., Al-Shuaibi, Y. S., \& Ouhtit, A. (2012). Folate and vitamin B12 deficiency and hyperhomocysteinemia promote oxidative stress in adult type 2 diabetes. Nutrition, 28(7-8), e23-26. http:// dx.doi.org/10.1016/j.nut.2012.01.005. PMid:22595450.

Almeida, J., \& Ball, B. A. (2005). Effect of a-tocopherol andtocopherol succinate on lipid peroxidation in equine spermatozoa. Animal Reproduction Science, 87(3-4), 321-337. http://dx.doi.org/10.1016/j.anireprosci.2004.12.004. PMid:15911181.

Arikan, S., \& Rodway, R. G. (2000). Effect of cyclodextrin-encapsulated $\beta$-carotene on progesterone production by bovine luteal cells. Animal Reproduction Science, 64(3-4), 149-160. http://dx.doi.org/10.1016/s03784320(00)00202-5. PMid:11121892.

Arruda, R. P., Silva, D. F., Alonso, M. A., Andrade, A. F. C., Nascimento, J., Gallego, A. M., Martins, S. M. M. K., \& Granato, T. M. (2010). Nutraceuticals in reproduction of bulls and stallions. Revista Brasileira de Zootecnia, 39(suppl spe), 393-400. http://dx.doi.org/10.1590/S1516-35982010001300043.

Beckett, G. J., \& Arthur, J. R. (2005). Selenium and endocrine systems. The Journal of Endocrinology, 184(3), 455-465. http://dx.doi.org/10.1677/joe.1.05971. PMid:15749805.

Bertechini, A. G. (1997). Nutrição de monogástricos (255 p ). Lavras: Ed FAEPE/UFLA.

Bornman, M. S., du Toit, D., Otto, B., Müller, I. I., Hurter, P., \& du Plessis, D. J. (1989). Seminal carnitine, epididymal function and spermatozoa motility. South African Medical Journal, 75(1), 20-21. PMid:2911777.

Bratton, R. W., Salisbury, G. W., Tanabe, T., Branton, C., Mercier, E., \& Loosli, J. K. (1948). Breeding behavior, spermatogenesis, and semen production of mature dairy bulls fed rations low in carotene. Journal of Dairy Science, 31(9), 779-791. http://dx.doi.org/10.3168/jds.S0022-0302(48)92258-9.

Brigelius-Flohe, R., \& Traber, M. G. (1999). Vitamin E: function and metabolism. The FASEB Journal, 13(10), 11451155. http://dx.doi.org/10.1096/fasebj.13.10.1145. PMid:10385606.

Brinsko, S. T., Varner, D. D., Love, C. C., Blanchard, T. L., Day, B. C., \& Wilson, M. E. (2005). Effect of feeding a DHA-enriched nutraceutical on the quality of fresh, cooled and frozen stallion semen. Theriogenology, 63(5), 1519-1527. http://dx.doi.org/10.1016/j.theriogenology.2004.07.010. PMid:15725455.

Brown, K. M., \& Arthur, J. R. (2001). Selenium, selenoproteins and human health: a review. Public Health Nutrition, 4(2B), 593-599. http://dx.doi.org/10.1079/PHN2001143. PMid:11683552.

Burton, G. W., \& Traber, M. G. (1990). Vitamin E: antioxidant activity, bio kinetics, and bioavailability. Annual Review of Nutrition, 10(1), 357-382. http://dx.doi.org/10.1146/annurev.nu.10.070190.002041. PMid:2200468.

Carvalho, O. F., Ferreira, J. D. J., Silveira, N. A., \& Freneau, G. E. (2002). Efeito oxidativo do óxido nítrico e infertilidade no macho. Jornal Brasileiro de Patologia e Medicina Laboratorial, 38(1), 33-38. http://dx.doi. org/10.1590/S1676-24442002000100007.

Casano, R., Orlando, C., Caldini, A. L., Barni, T., Natali, A., \& Serio, M. (1987). Simultaneous measurement of seminal l-carnitine, a,1-4-glucosidase, and glycerylphophorylcholine in azoospermic and oligozoospermic patients. Fertility and Sterility, 47(2), 324-328. http://dx.doi.org/10.1016/S0015-0282(16)50013-2. PMid:3102288.

Cerolini, S., Kelso, K. A., Noble, R. C., Speake, B. K., Pizzi, F., \& Cavalchini, L. G. (1997). Relationship between spermatozoon lipid composition and fertility during aging of chickens. Biology of Reproduction, 57(5), 976980. http://dx.doi.org/10.1095/biolreprod57.5.976. PMid:9369160.

Chinoy, N. J., Mehta, R. R., Seethalakshmi, L., Sharma, J. D., \& Chinoy, M. R. (1986). Effects of vitamin C deficiency on physiology of male reproductive organs of guines pigs. International Journal of Fertility, 31(3), 232-239. PMid:2875967.

Colagar, A. H., \& Marzony, E. T. (2009). Ascorbic acid in human seminal plasma: determination and its relationship to sperm quality. Journal of Clinical Biochemistry and Nutrition, 45(2), 144-149. http://dx.doi.org/10.3164/ jcbn.08-251. PMid:19794921.

Colenbrander, B., Fazeli, A. R., van Buiten, A., Parlevliet, J., \& Gadella, B. M. (1992). Assessment of sperm cell membrane integrity in the horse. Acta Veterinaria Scandinavica, 88, 49-58. PMid:1283655. 
Conquer, J. A., Martin, J. B., Tummon, I., Watson, L., \& Tekpetey, F. (1999). Fatty acid analysis of blood, serum, seminal plasma, and spermatozoa of normozoospermic vs. asthenozoospermic males. Lipids, 34(8), 793-799. http://dx.doi.org/10.1007/s11745-999-0425-1. PMid:10529089.

Conquer, J. A., Martin, J. B., Tummon, I., Watson, L., \& Tekpetey, F. (2000). Effect of DHA supplementation on DHA status and sperm motility in asthenozoospermic males. Lipids, 35(2), 149-154. http://dx.doi.org/10.1007/ BF02664764. PMid:10757545.

Cotgreave, I. A., Moldeus, P., \& Orrenius, S. (1988). Host biochemical defense mechanisms against prooxidants. Annual Review of Pharmacology and Toxicology, 28(1), 189-212. http://dx.doi.org/10.1146/annurev.pa.28.040188.001201. PMid:3289484.

Crimmel, A. S., Conner, C. S., \& Monga, M. (2001). Withered yang: a review of traditional Chinese medical treatment of male infertility and erectile dysfunction. Journal of Andrology, 22(2), 173-182. PMid:11229790.

Dawson, E. B., Harris, W. A., Rankin, W. E., Charpentier, L. A., \& McGanity, W. J. (1987). Effect of ascorbic acid on male fertility. Annals of the New York Academy of Sciences, 498, 312-323. http://dx.doi.org/10.1111/j.1749-6632.1987. tb23770.x. PMid:3476000.

De-Aloysio, D., Mantuano, R., Mauloni, M., \& Nicoletti, G. (1982). The clinical use of arginine aspartate in male infertility. Acta Europaea Fertilitatis, 13(3), 133-167. PMid:6820754.

Dharti, T. S., Gandhi, S., \& Shah, M. (2010). Nutraceuticals - Portmanteau of science and nature. International Journal of Pharmaceutical Sciences Review and Research, 5, 33-38.

Drokin, S. I., Vaisberg, T. N., Kopeika, E. F., Miteva, K. D., \& Pironcheva, G. L. (1999). Effect of cryopreservation on lipids and some physiological features of spermatozoa from rams pastured in highlands and in valleys. Cytobios, 100(393), 27-36. PMid:10643642.

Dusse, L. M. S., Vieira, L. M., \& Carvalho, M. G. (2003). Revisão sobre óxido nítrico. Jornal Brasileiro de Patologia e Medicina Laboratorial, 39(4), 343-350. http://dx.doi.org/10.1590/S1676-24442003000400012.

Erb, R. E., Andrews, F. N., Hauge, S. M., \& King, W. A. (1947). Observations on vitamin A deficiency in young dairy bulls. Journal of Dairy Science, 30(9), 687-702. http://dx.doi.org/10.3168/jds.S0022-0302(47)92387-4.

Ford, W., \& Whittington, K. (1998). Antioxidant treatment for male subfertility: a promise that remains unfulfilled. Human Reproduction,13(6), 1416-1419. http://dx.doi.org/10.1093/oxfordjournals.humrep.a019707. PMid:9688362.

Freitas, M. L., Bouéres, C. S., Pignataro, T. A., Gonçalves de Oliveira, F. J., de Oliveira Viu, M. A., \& de Oliveira, R. A. (2016). Quality of fresh, cooled and frozen semen from stallions supplemented with antioxidants and fatty acids. Journal of Equine Veterinary Science, 46, 1-6. http://dx.doi.org/10.1016/j.jevs.2016.07.003.

Gliozzi, T. M., Zaniboni, L., Maldjian, A., Luzi, F., Maertens, L., \& Cerolini, S. (2009). Quality and lipid composition of spermatozoa in rabbit fed DHA and vitamin E rich diets. Theriogenology, 71(6), 910-919. http://dx.doi. org/10.1016/j.theriogenology.2008.10.022. PMid:19121864.

Grady, S. T., Cavinder, C. A., \& Brinsko, S. P. (2009). Dietary supplementation of two varying sources of n-3 fatty acids and subsequent effects on fresh, cooled and frozen seminal characteristics of stallions. PAS, 25, 768-773.

Greco, E., Iacobelli, M., Rienzi, L., Ubaldi, F., Ferrero, S., \& Tesarik, J. (2005). Reduction of the incidence of sperm DNA fragmentation by oral antioxidante treatment. Journal of Andrology, 26(3), 349-353. http://dx.doi. org/10.2164/jandrol.04146. PMid:15867002.

Hafeman, D. G., Sunde, R. A., \& Hoekstra, W. G. (1974). Effect of dietary selenium on erythrocyte and liver glutatione peroxidase in the rat. The Journal of Nutrition, 104(5), 580-587. http://dx.doi.org/10.1093/jn/104.5.580. PMid:4823943.

Holt, L. E., \& Albanese, A. A. (1944). Observations on amino acid deficiencies in man. Transactions of the Association of American Physicians, 58, 143-156.

Hulse, J. D., Ellis, S. R., \& Henderson, L. M. (1978). Carnitine biosynthesis. Beta-hydroxylation of trimethyllysine by na alpha-ketoglutarate-dependent mitochondrial dioxygenase. The Journal of Biological Chemistry, 253(5), 1654-1659. PMid:627563.

Imai, H., \& Nakagawa, Y. (2003). Biological significance of phospholipids hydroperoxidegluthathione peroxidase (PHGPx, GPx 4) in mammalian cells. Free Radical Biology \& Medicine, 34(2), 145-169. http://dx.doi.org/10.1016/ S0891-5849(02)01197-8. PMid:12521597.

Jeulin, C., Dacheux, J. L., \& Soufir, J. C. (1994). Uptake and release of free L-carnitine by boar epididymal spermatozoa in vitro and subsequent acetylation rate. Journal of Reproduction and Fertility, 100(1), 263-271. http://dx.doi. org/10.1530/jrf.0.1000263. PMid:8182599.

Jones, R., \& Mann, T. (1973). Lipid peroxidation in spermatozoa. Proceedings of the Royal Society of London, 184(1074), 103-107. http://dx.doi.org/10.1098/rspb.1973.0035. PMid:4147946.

Kamal-Eldin, A., \& Appelqvist, L.-Å. (1996). The chemistry and antioxidant properties of tocopherols and tocotrienols. Lipids, 31(7), 671-701. http://dx.doi.org/10.1007/BF02522884. PMid:8827691.

Kao, S.-H., Chao, H.-T., Chen, H.-W., Hwang, T. I. S., Liao, T.-L., \& Wei, Y.-H. (2008). Increase in oxidative stress in human sperm with lower motility. Fertility and Sterility, 89(5), 1183-1190. http://dx.doi.org/10.1016/j. fertnstert.2007.05.029. PMid:17669405.

Kefer, J. C., Agarwal, A., \& Sabanegh, E. (2009). Role of antioxidants in the treatment of male infertility. International Journal of Urology, 16(5), 449-457. http://dx.doi.org/10.1111/j.1442-2042.2009.02280.x. PMid:19383039.

Kelso, K. A., Redpath, A., Noble, R. C., \& Speake, B. K. (1997). Lipid and antioxidant changes in spermatozoa and seminal plasma throughout the reproductive period of bulls. Journal of Reproduction and Fertility, 109(1), 1-6. http://dx.doi.org/10.1530/jrf.0.1090001. PMid:9068407. 
Kirschvink, N., de Moffarts, B., \& Lekeux, P. (2008). The oxidant/antioxidant equilibrium in horses. Veterinary Journal (London, England), 177(2), 178-191. http://dx.doi.org/10.1016/j.tvjl.2007.07.033. PMid:17897849.

Knowles, R. G., Palacios, M., Palmer, R. M., \& Moncada, S. (1989). Formation of nitric oxide from L-arginine in the central nervous system: a transduction mechanism for stimulation of the soluble guanylate cyclase. Proceedings of the National Academy of Sciences of the United States of America, 86(13), 5159-5162. http://dx.doi. org/10.1073/pnas.86.13.5159. PMid:2567995.

Ko, E. Y., \& Sabanegh, E. S. (2014). The role of nutraceuticals in male fertility. The Urologic Clinics of North America, 41(1), 181-193. http://dx.doi.org/10.1016/j.ucl.2013.08.003. PMid:24286776.

Kozink, D. M., Estienne, M. J., Harper, A. F., \& Knight, J. W. (2004). Effects of dietary L-carnitine supplementation on semen characteristics in boars. Theriogenology, 61(7-8), 1247-1258. http://dx.doi.org/10.1016/j. theriogenology.2003.07.022. PMid:15036959.

Lamirande, E., \& Lamothe, G. (2009). Reactive oxygeninduced reactive oxygen formation during human sperm capacitation.Free Radical Biology \& Medicine, 46(4), 502-510. http://dx.doi.org/10.1016/j.freeradbiomed.2008.11.004. PMid:19071212.

Lamirande, E., Jiang, H., Zini, A., Kodama, H., \& Gagnon, C. (1997). Reactive oxygen species and sperm physiology. Reviews of Reproduction, 2(1), 48-54. http://dx.doi.org/10.1530/ror.0.0020048. PMid:9414465.

Maiorino, M., Bosello, V., Ursini, F., Foresta, C., Garolla, A., Scapin, M., Sztajer, H., \& Flohe, L. (2003). Genetic variations of gpx-4 and male infertility in human. Biology of Reproduction, 68(4), 1134-1141. http://dx.doi. org/10.1095/biolreprod.102.007500. PMid:12606444.

Mason, K. E. (1933). Differences in testis injury and repair after vitamin A-deficiency. Vitamin E-deficiency and inanition. The American Journal of Anatomy, 52(2), 153-239. http://dx.doi.org/10.1002/aja.1000520202.

McCann, S. M., Mastronardi, C., Walczewska, A., Karanth, S., Rettori, V., \& Yu, W. H. (1999). The role of nitric oxide in reproduction. Brazilian Journal of Medical and Biological Research, 32(11), 1367-1379. http://dx.doi.org/10.1590/ S0100-879X1999001100007. PMid:10559838.

Menchini-Fabris, G. F., Canale, D., Izzo, P. L., Olivieri, L., \& Bartelloni, M. (1984). Free l-carnitine in human semen: its variability in different andrologic pathologies. Fertility and Sterility, 42(2), 263-267. http://dx.doi.org/10.1016/ s0015-0282(16)48024-6. PMid:6430725.

Mendiola, J., Torres-Cantero, A. M., Vioque, J., Moreno-Grau, J. M., Ten, J., Roca, M., Moreno-Grau, S., \& Bernabeu, R. (2010). A low intake of antioxidant nutrients is associated with poor semen quality in patients attending fertility clinics. Fertility and Sterility, 93(4), 1128-1133. http://dx.doi.org/10.1016/j.fertnstert.2008.10.075. PMid:19147135.

Mroueh, A. (1970). Effect of arginine on oligospermia. Fertility and Sterility, 21(3), 217-219. http://dx.doi.org/10.1016/ S0015-0282(16)37384-8. PMid:5435745.

Neuman, S. L., Lin, T. L., \& Heste, P. Y. (2002). The effect of dietary carnitine on semen traits of White Leghorn roosters. Poultry Science, 81(4), 495-503. http://dx.doi.org/10.1093/ps/81.4.495. PMid:11989749.

Noack-Füller, G., Beer, C., \& Seibert, H. (1993). Cadmium, lead, selenium, and zinc in semen of occupationally unexposed men. Andrologia, 25(1), 7-12. http://dx.doi.org/10.1111/j.1439-0272.1993.tb02674.x. PMid:8427423.

Nordberg, J., \& Árner, E. S. J. (2001). Reactive oxygen species, antioxidants, and the mammalian thioredoxin system. Free Radical Biology \& Medicine, 31(11), 1287-1312. http://dx.doi.org/10.1016/S0891-5849(01)00724-9. PMid:11728801.

O'Bryan, M. K., Zini, A., Cheng, C. Y., \& Schlegel, P. N. (1998). Human sperm endothelial nitric oxide synthase expression: correlation with sperm motility. Fertility and Sterility, 70(6), 1143-1147. http://dx.doi.org/10.1016/ S0015-0282(98)00382-3. PMid:9848308.

Oliveira, R. A., Wolf, C. A., Oliveira Viu, M. A., \& Gambarini, M. L. (2013). Addition of glutathione to an extender for frozen equine semen. Journal of Equine Veterinary Science, 33(12), 1148-1152. http://dx.doi.org/10.1016/j. jevs.2013.05.001.

Palamanda, J. R., \& Kehrer, J. P. (1993). Involvement of vitamin E and protein thiols in the inhibition of microsomal lipid peroxidation by glutathione. Lipids, 28(5), 427-431. http://dx.doi.org/10.1007/BF02535941. PMid:8316051.

Palmero, S., Bottazzi, C., Costa, M., Leone, M., \& Fugassa, E. (2000). Metabolic effects of L-carnitine on prepubertal rat Sertoli cells. Hormone and Metabolic Research. Hormon-und Stoffwechselforschung. Hormones et Metabolisme 32(3), 87-90. http://dx.doi.org/10.1055/s-2007-978596. PMid:10786925.

Pesch, S., Bergmann, M., \& Bostedt, H. (2006). Determination of some enzymes and macro- and microelements in stallion seminal plasma and their correlations to semen quality. Theriogenology, 66(2), 307-313. http://dx.doi. org/10.1016/j.theriogenology.2005.11.015. PMid:16413936.

Pryor, J. P., Blandy, J. P., Evans, P., Chaput De Saintonge, D. M., \& Usherwood, M. (1978). Controlled clinical trial of arginine for infertile men with oligozoospermia. British Journal of Urology, 50(1), 47-50. http://dx.doi. org/10.1111/j.1464-410X.1978.tb02765.x. PMid:343863.

Reynolds, E. (2006). Vitamin B12, folic acid, and the nervous system. Lancet Neurology, 5(11), 949-960. http:// dx.doi.org/10.1016/S1474-4422(06)70598-1. PMid:17052662.

Rillo M.R. (1982). Reproduccion e inseminacion artificial porcina (pp. 54-73). Espanha: Ed Aedos.

Ryan, T. C., Weil, G. J., Newburger, P. E., Haugland, R., \& Simons, E. R. (1990). Measurement of superoxide release in the phagovacuoles of immune complex-stimulated human neutrophils. Journal of Immunological Methods, 130(2), 223-233. http://dx.doi.org/10.1016/0022-1759(90)90052-W. PMid:2165099. 
Safarinejad, M. R., \& Safarinejad, S. (2009). Efficacy of selenium and/or N-acetyl-cysteine for improving semen parameters in infertile men: a double-blind, placebo controlled, randomized study. The Journal of Urology, 181(2), 741-751. http://dx.doi.org/10.1016/j.juro.2008.10.015. PMid:19091331.

Salem, M. H., Kamel, K. I., Yousef, M. I., Hassan, G. A., \& EL-Nouty, F. D. (2001). Protective role of ascorbic acid to enhance semen quality of rabbits treated with sublethal doses of aflatoxin B1. Toxicology, 162(3), 209-218. http://dx.doi.org/10.1016/S0300-483X(01)00366-3. PMid:11369116.

Schachter, A., Goldman, J. A., \& Zukerman, Z. (1973). Treatment of oligospermia with the amino acid arginine. The Journal of Urology, 110(3), 311-313. http://dx.doi.org/10.1016/S0022-5347(17)60199-X. PMid:4725736.

Schmid-Lausigk, Y., \& Aurich, C. (2014). Influences of a diet supplemented with linseed oil and antioxidants on quality of equine semen after cooling and cryopreservation during winter. Theriogenology, 81(7), 966-973. http://dx.doi.org/10.1016/j.theriogenology.2014.01.021. PMid:24576708.

Scibona, M., Meschini, P., Capparelli, S., Pecori, C., Rossi, P., \& Menchini Fabris, G. F. (1994). L-arginine and male infertility. Minerva Urologica e Nefrologica, 46(4), 251-253. PMid:7701414.

Solomon, L. R. (2007). Disorders of cobalamin (Vitamin B12) metabolism: Emerging concepts in pathophysiology, diagnosis and treatment. Blood Reviews, 21(3), 113-130. http://dx.doi.org/10.1016/j.blre.2006.05.001. PMid:16814909.

Sonmez, M., Turk, G., \& Yuce, A. (2005). The effect of ascorbic acid supplementation on sperm quality, lipid peroxidation and testosterone levels of male Wistar rats. Theriogenology, 63(7), 2063-2072. http://dx.doi. org/10.1016/j.theriogenology.2004.10.003. PMid:15823361.

Srivastava, S., \& Agarwal, A. (2010). Effect of anion channel blockers on L-arginine action in spermatozoa from asthenospermic men.Andrologia, 42(2), 76-82. http://dx.doi.org/10.1111/j.1439-0272.2009.00959.x. PMid:20384796.

Surai, P. F., Brillard, J. P., Speake, B. K., Blesbois, E., Seigneurin, F., \& Sparks, N. H. (2000). Phospholipids fatty acid composition, vitamin E content and susceptibility to lipid peroxidation of duck spermatozoa. Theriogenology, 53(5), 1025-1039. http://dx.doi.org/10.1016/S0093-691X(00)00249-1. PMid:10798481.

Tanimura, J. (1967). Studies on arginine in human semen. Part II. The effects of medication with L-arginine- HCl on male infertility. Bulletin of the Osaka Medical School, 13(2), 84-89. PMid:6080242.

Thiele, J. J., Freisleben, H. J., Fuchs, J., \& Ochsendorf, F. R. (1995). Ascorbic acid and urate in human seminal plasma: determination and interrelationships with chemiluminescence in washed semen. Human Reproduction (Oxford, England), 10(1), 110-115. http://dx.doi.org/10.1093/humrep/10.1.110. PMid:7745037.

Ursini, F., Heim, S., Kiess, M., Maiorino, M., Roveri, A., Wissing, J., \& Flohé, L. (1999). Dual function of the selenoproteinPHGPx during sperm maturation. Science, 285(5432), 1393-1396. http://dx.doi.org/10.1126/ science.285.5432.1393. PMid:10464096.

Vezina, D., Mauffette, F., Roberts, K. D., \& Bleau, G. (1996). Selenium- vitamin E supplementation in infertile men. Effects on semen parameters and micronutriente levels and distribution. Biological Trace Element Research, 53(1-3), 65-83. http://dx.doi.org/10.1007/BF02784546. PMid:8862739.

Vicari, E., Lavignera, S., \& Calogero, A. (2002). Antioxidant treatment with carnitines is effective in infertile patients with prostatovesiculoepididymitis and elevated seminal leukocyte concentrations after treatment with nonsteroidal anti-inflammatory compounds. Fertility and Sterility, 78(6), 1203-1208. http://dx.doi.org/10.1016/ S0015-0282(02)04350-9. PMid:12477513.

Vignini, A., Alidori, A., Montesi, L., Raffaelli, F., Nanetti, L., Bertoli, E., \& Mazzanti, L. (2011). Vitamin E, diabetes and related diseases: an update. Mediterranean Journal of Nutrition and Metabolism, 4(1), 3-9. http://dx.doi, org/10.1007/s12349-010-0006-y.

Watanable, T., \& Endo, A. (1991). Effects of selenium deficiency on sperm morphology and spermatocyte chromosomes in mice. Mutation Research, 262(2), 93-99. http://dx.doi.org/10.1016/0165-7992(91)90113-I. PMid:2000100.

Wolbach, S. B., \& Howe, P. R. (1925). Tissues changes following deprivation of fat-soluble A vitamin. The Journal of Experimental Medicine, 42(6), 753-777. http://dx.doi.org/10.1084/jem.42.6.753. PMid:19869087.

Yeste, M., Barrera, X., Coll, D., \& Bonet, S. (2011). The effects on boar sperm quality of dietary supplementation with omega-3 polyunsaturated fatty acids differ among porcine breeds. Theriogenology, 76(1), 184-196. http:// dx.doi.org/10.1016/j.theriogenology.2011.01.032. PMid:21458051.

Young, S. S., Eskenazi, B., Marchetti, F. M., Block, G., \& Wyrobek, A. J. (2008). The association of folate, zinc, and antioxidant intake with sperm aneuploidy in healthy non-smoking men. Human Reproduction (Oxford, England), 23(5), 1014-1022. http://dx.doi.org/10.1093/humrep/den036. PMid:18353905.

Zöpfgen, A., Priem, F., Sudhoff, F., Jung, K., Lenk, S., Loening, S. A., \& Sinha, P. (2000). Relationship between semen quality and the seminal plasma components carnitine, alpha-glucosidase, fructose, citrate and granulocyte elastase in infertile men compared with a normal population. Human Reproduction (Oxford, England), 15(4), 840-845. http://dx.doi.org/10.1093/humrep/15.4.840. PMid:10739829. 